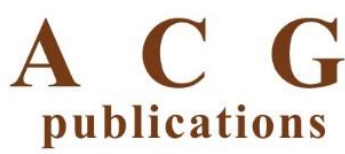

Org. Commun. 14:3 (2021) 270-279

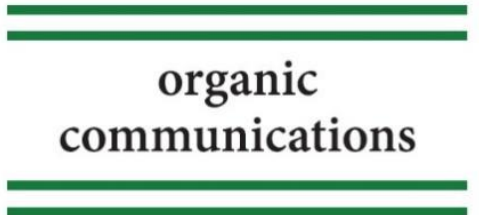

\title{
Synthesis of carbazole-based acetyl benzohydrazides targeting urease enzyme inhibition İrfan Çapan $\mathbb{1}^{1,2^{*}}$
}

\author{
${ }^{1}$ Gazi University, Technical Sciences Vocational College, Department of Material and Material \\ Processing Technologies, 06560 Ankara-Türkiye \\ ${ }^{2}$ Gazi University, Faculty of Pharmacy, Department of Pharmaceutical Chemistry, Ankara-Türkiye
}

(Received July 23, 2021; Revised August 01, 2021; Accepted August 10, 2021)

\begin{abstract}
The carbazole skeleton is the key structural motif of many bioactive molecules including synthetic and natural products. The carbazole derivatives bearing different functional groups have important pharmacological activities and are widely used in medicine and pharmacology. Ethyl $9 H$-carbazol-9-yl acetate was synthesized from the reaction of the carbazole with ethyl bromoacetate. The acetate ester derivative was converted into the 2- $(9 \mathrm{H}-$ carbazol-9-yl) acetohydrazide through treatment with hydrazine hydrate. The target compounds were synthesized by using carbazole-hydrazides and various aromatic acid chlorides. Acetyl benzohydrazide derivatives were prepared from the nucleophilic addition-elimination reactions of corresponding benzoyl chloride and 2-(9H-carbazol-9-yl) acetohydrazide in THF at room temperature condition. The structures of all newly synthesized compounds were characterized using different spectroscopic techniques, such as FT-IR, ${ }^{1} \mathrm{H}$ NMR, ${ }^{13} \mathrm{C}$ NMR, and HRMS. The urease enzyme activities of these compounds were investigated using Jack bean urease as the model enzyme.
\end{abstract}

Keywords: Acetyl benzohydrazide; carbazole; urease inhibitors. @2021 ACG Publication. All right reserved.

\section{Introduction}

Carbazole, an important nitrogen-containing aromatic heterocyclic skeleton, occurs predominantly in numerous natural products and bioactive molecules. Various functional groups have easily substituted structurally into the carbazole ring, since carbazole has the desired electronic and charge-carrying properties as well as the large $\pi$-conjugated system. ${ }^{1-4}$ The carbazole derivatives are widely used in medicine and pharmacology. These compounds display a range of important biological properties including antiviral, antifungal, anti-inflammatory, antioxidant, antidiabetic, hepatoprotective, anti-protozoan, sedative properties, and topoisomerase II inhibition ability. ${ }^{5-10}$ Synthesis of new chemotherapeutics gains importance because of the cell exchange with synthetic compounds used in cancer treatment. In recent years, the reasons for the increased interest in carbazole derivatives are that they are highly effective in the treatment of brain tumors and leukemia, especially breast and kidney cancer, by showing anti-tumor, ${ }^{11}$ anti-HIV activity. ${ }^{12}$ In addition, some carbazole derivatives have been used in the treatment of neurological disorders like multiple sclerosis, Parkinson's, and Alzheimer's diseases (Figure 1A). ${ }^{13}$ Moreover, these compounds do not cause gene mutation, which is a potential risk factor for anti-cancer agents, do not bring about blood poisoning and side effects.

\footnotetext{
* Corresponding author: E-Mail: irfancapan@gazi.edu.tr, Phone: + 90312202 3229; Fax: + 903123543835. 
Çapan, Org. Commun. (2021) 14:3 270-279

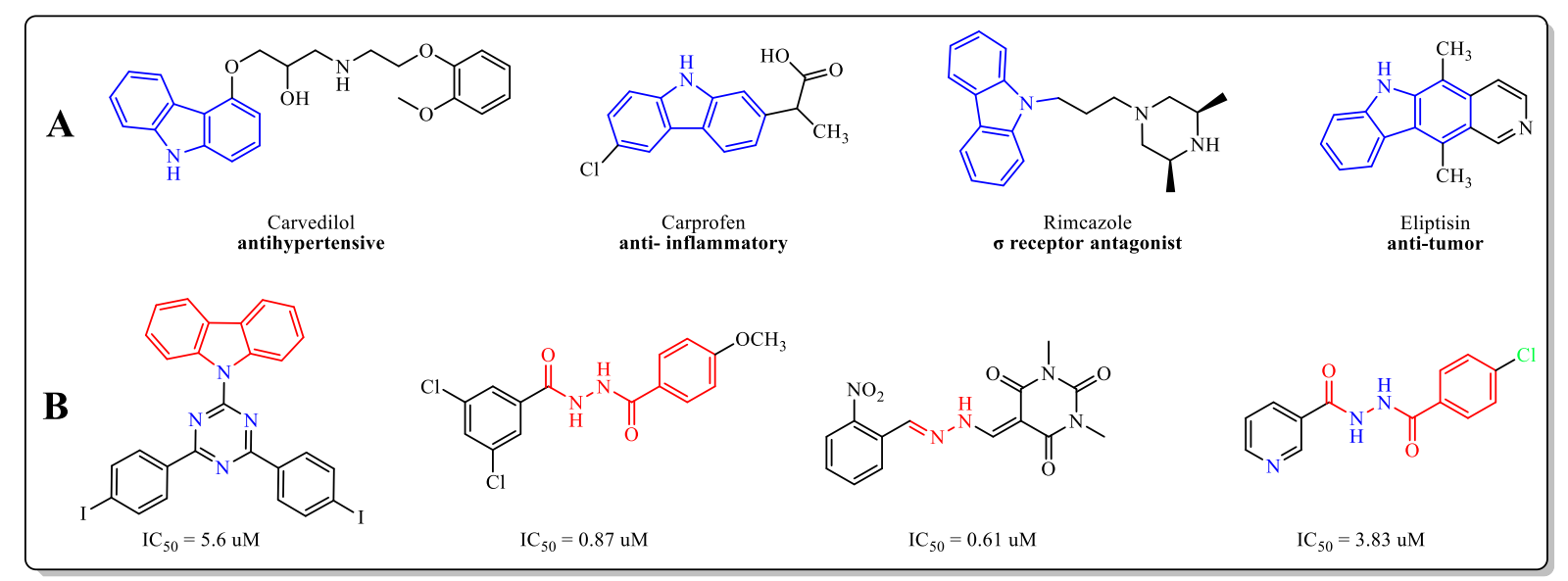

Figure 1. (A) Some carbazole-based biologically active compounds with different functional groups; (B) the urease inhibitors

Hydrazides are acylated derivatives of hydrazine and use as starting materials for the synthesis of pharmaceutical products. ${ }^{14-16}$ Besides, they are known to have many pharmacological activities including anti-inflammatory, anti-tumor, and anti-tuberculosis. ${ }^{17-18}$

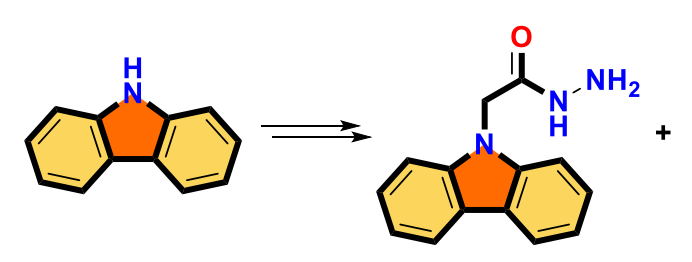

2

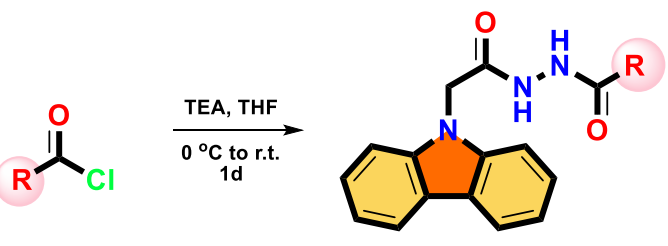

3-9<smiles>O=C(Cn1c2ccccc2c2ccccc21)NNC(=O)c1ccccc1</smiles>

Compound 3<smiles>O=C(Cn1c2ccccc2c2ccccc21)NNC(=O)c1ccccc1Cl</smiles>

Compound 4<smiles>O=C(Cn1c2ccccc2c2ccccc21)NNC(=O)c1cccc(Cl)c1</smiles>

Compound 5<smiles>O=C(Cn1c2ccccc2c2ccccc21)NNC(=O)c1ccc(Cl)cc1</smiles>

Compound 6<smiles>O=C(Cn1c2ccccc2c2ccccc21)NNC(=O)c1ccc(F)cc1</smiles>

Compound 7<smiles>C/C=C\C=C/C</smiles>

Compound 8<smiles>COc1ccc(C(=O)NNC(=O)Cn2c3ccccc3c3ccccc32)cc1</smiles>

Compound 9

Figure 2. Synthesis scheme of compounds 3-9 
Synthesis of carbazole-based acetyl benzohydrazides targeting urease enzyme inhibition

Urease (urea amidohydrolase) is an enzyme that catalyzes the hydrolysis of urea to ammonia and carbamate in living organisms and accelerates the rate of this conversion a hundred trillion times ${ }^{19}$ that cause a significant increase in $\mathrm{pH}$ and are responsible for the negative effects of urease activity. This enzyme responsible for urinary tract and gastrointestinal infections and the inhibition of the urease enzyme is very important as it plays a key role in the treatment of several urinary and gastrointestinal tract infections. ${ }^{19-20}$ Urease has several functions and the urease inhibition has received special attention and many antiurease agents have been reported in the last few years. Although different compounds belonging to different classes such as hydroxamic acid derivatives, hydroxyurea, phosphorodiamidates, urea derivatives, imidazoles, kinins, and thiols, have been reported as the urease inhibitors, only a few have advanced to clinical trials (Figure 1B). ${ }^{21-22}$

Although several chemical molecules with therapeutic potential have been reported as urease enzyme inhibitors, some disadvantages such as toxicity and safety of these inhibitors make the synthesis of new, potent, and safe inhibitors very important. In this study, the synthesis of some new carbazolebased acetyl benzohydrazides was reported as a result of the efforts to identify new nitrogen-containing aromatic and non-aromatic heterocyclic compounds that may be valuable in designing biologically active compounds (Figure 2).

\section{Experimental}

\subsection{Chemical Material and Apparatus}

The solvents used in the study are of analytical purity. The reagents used were obtained from Sigma-Aldrich \& Merck (Germany) and ABCR (Germany) and the solvents were obtained from domestic and foreign sources. THF used in the anhydrous environment was distilled using metallic $\mathrm{Na}$ / benzophenone. The reactions were carried out under suitable temperatures and conditions using DMF, DMSO, THF, dichloromethane, toluene, ethyl alcohol as the solvent.

The melting points of the compounds were determined with the SMP50 Automatic Melting Point apparatus and values are given uncorrected. Silica gel 60 F254 aluminum plates were used for the purity controls of the compounds by thin-layer chromatography. Hexane: ethyl acetate, dichloromethane: methanol, and dichloromethane: ethyl acetate was used as solvent systems. Camag UV lamp (254 and $366 \mathrm{~nm}$ ) was used to follow the reaction. The purification processes of the synthesized compounds were carried out with the Teledyne ISCO Combiflash ${ }^{\circledR}$ Automatic Flash Chromatography System with a UV detector. Ready-made RediSep ${ }^{\circledR}$ silica columns (12g, 24g, and 40g) and Grace Reveleris ${ }^{\circledR}$ silica columns $(12 \mathrm{~g}, 24 \mathrm{~g}$, and $40 \mathrm{~g}$ ) were used as stationary phase, dichloromethane: methanol and hexane: ethyl acetate, dichloromethane: ethyl acetate gradient solvent systems were used as mobile phases. The purity of the compounds was checked by TLC and UPLC / MS-TOF analyzes.

The ${ }^{1} \mathrm{H}$ and ${ }^{13} \mathrm{C}_{\mathrm{APT}}-\mathrm{NMR}$ spectra of the synthesized compounds were taken with their solutions in $\mathrm{CDCl}_{3}$, DMSO or by dropping trifluoroacetic acid to these solutions in Bruker DPX-400 HighPerformance Digital FT-NMR Spectrometer for ${ }^{1} \mathrm{H}$ NMR at $400 \mathrm{MHz}$, for ${ }^{13} \mathrm{C}$ NMR at $100 \mathrm{MHz}$ frequency, and the chemical shift values $(\delta)$ was evaluated in ppm scale. Coupling constants $(J)$ are given in Hertz $(\mathrm{Hz})$. FT-IR spectra of the synthesized compounds were taken with Perkin Elmer Spectrum 400 device by ATR technique. HRMS spectra of the synthesized compounds were taken from their solutions in methanol using positive ion $(\mathrm{ESI}+)$ electrospray ionization techniques with Waters LCT Premier XE UPLC / MSTOF system by MassLynx 4.1 software. Aquity BEH C18 column (2.1 x $100 \mathrm{~mm} 1.7 \mu \mathrm{M}$, flow rate: $0.3 \mathrm{~mL} / \mathrm{min})$ as stationary phase, $\mathrm{CH}_{3} \mathrm{CN}: \mathrm{H}_{2} \mathrm{O}(1 \%-90 \%)$ gradient solvent system containing formic acid (0.1\%) as mobile phase was used.

ChemDraw19 was used as a molecule drawing program, PerkinElmer Spectrum for analyzing IR spectra, NMR, FID, MestReNova 12 for processing LC-MS data and analysis of NMR spectra. 
Çapan, Org. Commun. (2021) 14:3 270-279

\subsection{Biological Materials and Apparatus}

Biological activity experiments were conducted in the laboratories of Atlas Biotechnology Company. Except for phenol (Merck), urease (Jack Bean), urea, thiourea, ethanol, dimethyl sulfoxide, sodium hydroxide, di-potassium hydrogen phosphate, potassium dihydrogen phosphate, sodium nitroprusside chemicals, and sodium hypochlorite solutions were supplied from the Sigma Company. Memmert UN55 as incubators and Heales MB530 microplate reader devices were used for read increased absorbance values at the appropriate wavelength.

\subsection{Chemistry}

Ethyl 9H-carbazol-9-yl acetate (compound1) and 2-(9H-carbazol-9-yl) acetohydrazide (compound 2) are known compounds and the synthesis of these compounds was carried out according to the cited literature. ${ }^{3}$ Initially, compound 1 was synthesized from the reaction of the carbazole with ethyl acetoacetate. Then, compound 2 was converted into the 2-(9H-carbazol-9-yl) acetohydrazide through treatment with hydrazine hydrate.

\subsubsection{General Procedure for Synthesis of Compound (3-9)}

To the THF (20 mL) solution of the hydrazide (compound $2,1.04 \mathrm{mmol}, 250 \mathrm{mg}$ ), triethylamine (TEA, $1.04 \mathrm{mmol}, 134 \mu \mathrm{L}$ ) was added. The required benzoyl chloride derivative $(1.04 \mathrm{mmol})$ was added dropwise to the reaction mixture cooled to $0{ }^{\circ} \mathrm{C}$ with an ice bath. After stirring for 30 minutes at this temperature, it was stirred at room temperature for one day. The precipitated colorless TEA salt was filtered off. The solvent was removed from the filtrate by a rotary evaporator. After the crude product was dissolved in $5 \mathrm{~mL}$ of methyl alcohol, it was added dropwise to $200 \mathrm{~mL}$ of cold water. The precipitated solid was filtered and dried under a vacuum. The crude products were purified by flash chromatography using $0 \% \rightarrow 10 \% \mathrm{MeOH}$ in $\mathrm{DCM}$ as the solvent mixture.

$N^{\prime}$-[2-(9H-carbazol-9-yl)acetyl]-benzohydrazide (3): White solid, Yield 78.5\%; m.p 265-267 ${ }^{\circ} \mathrm{C}$. FTIR (ATR, cm $\left.{ }^{-1}\right): 3260,3179(\mathrm{NH}), 1744,1651(\mathrm{C}=\mathrm{O}) .{ }^{1} \mathrm{H}$ NMR (400 MHz, DMSO-d $\left.d_{6}\right) \delta 10.55(\mathrm{~s}, 2 \mathrm{H})$, $8.17(\mathrm{~d}, J=7.7 \mathrm{~Hz}, 2 \mathrm{H}), 7.94-7.83(\mathrm{~m}, 2 \mathrm{H}), 7.65(\mathrm{~d}, J=8.2 \mathrm{~Hz}, 2 \mathrm{H}), 7.61-7.53(\mathrm{~m}, 1 \mathrm{H}), 7.48(\mathrm{td}, J$ $=8.5,4.0 \mathrm{~Hz}, 4 \mathrm{H}), 7.24(\mathrm{t}, J=7.5 \mathrm{~Hz}, 2 \mathrm{H}), 5.21(\mathrm{~s}, 2 \mathrm{H}) .{ }^{13} \mathrm{C}$ NMR $(101 \mathrm{MHz}, \mathrm{DMSO}) \delta 167.48,165.94$, 141.06, 132.76, 132.35, 128.94, 127.92, 126.16, 122.77, 120.63, 119.58, 109.99, 44.59. HRMS m/z calculated for $\mathrm{C}_{21} \mathrm{H}_{17} \mathrm{~N}_{3} \mathrm{O}_{2}[\mathrm{M}+\mathrm{H}]^{+} 344.132$, found: 344.156 .

$N^{\prime}-[2-(9 H$-carbazol-9-yl)acetyl]-2-chlorobenzohydrazide (4): White solid, Yield 83.6\%; m.p 235-237 ${ }^{\circ} \mathrm{C}$. FT-IR (ATR, $\mathrm{cm}^{-1}$ ): 3257, $3165(\mathrm{NH}), 1686,1658(\mathrm{C}=\mathrm{O}), 746(\mathrm{C}-\mathrm{Cl}) .{ }^{1} \mathrm{H}$ NMR (400 MHz, DMSO$\left.d_{6}\right) \delta 10.71(\mathrm{~s}, 1 \mathrm{H}), 10.48(\mathrm{~s}, 1 \mathrm{H}), 8.17(\mathrm{~d}, J=7.8 \mathrm{~Hz}, 2 \mathrm{H}), 7.63(\mathrm{~d}, J=8.2 \mathrm{~Hz}, 2 \mathrm{H}), 7.55-7.41(\mathrm{~m}$, 6H), 7.27 - 7.20 (m, 2H), 5.20 (s, 2H). ${ }^{13} \mathrm{C}$ NMR (101 MHz, DMSO) $\delta 167.12,165.65,141.07,134.93$, $131.96,130.85,130.29,129.74,127.59,126.16,122.78,120.62,119.58,109.98,44.50$. HRMS $\mathrm{m} / \mathrm{z}$ calculated for $\mathrm{C}_{21} \mathrm{H}_{16} \mathrm{ClN}_{3} \mathrm{O}_{2}[\mathrm{M}+\mathrm{H}]+378.093$, found: 378.107 .

$N^{\prime}$-[2-(9H-carbazol-9-yl)acetyl]-3-chlorobenzohydrazide (5): White solid, Yield 80.2\%; m.p 268-270 ${ }^{\circ} \mathrm{C}$. FT-IR (ATR, $\left.\mathrm{cm}^{-1}\right)$ : 3324, $3221(\mathrm{NH}), 1725,1665(\mathrm{C}=\mathrm{O}), 746(\mathrm{C}-\mathrm{Cl}) .{ }^{1} \mathrm{H}$ NMR (400 MHz, DMSO$\left.d_{6}\right) \delta 10.65(\mathrm{~d}, J=17.9 \mathrm{~Hz}, 2 \mathrm{H}), 8.17(\mathrm{dt}, J=7.7,0.9 \mathrm{~Hz}, 2 \mathrm{H}), 7.91(\mathrm{t}, J=1.9 \mathrm{~Hz}, 1 \mathrm{H}), 7.84(\mathrm{dt}, J=7.8$, $1.3 \mathrm{~Hz}, 1 \mathrm{H}), 7.69-7.60(\mathrm{~m}, 3 \mathrm{H}), 7.55(\mathrm{t}, J=7.9 \mathrm{~Hz}, 1 \mathrm{H}), 7.48(\mathrm{ddd}, J=8.3,7.1,1.2 \mathrm{~Hz}, 2 \mathrm{H}), 7.28-$ $7.20(\mathrm{~m}, 2 \mathrm{H}), 5.22(\mathrm{~s}, 2 \mathrm{H}) .{ }^{13} \mathrm{C}$ NMR (101 MHz, DMSO) $\delta 167.44,164.56,141.06,134.68,133.79$, $132.25,131.05,127.73,126.67,126.16,122.78,120.64,119.59,109.97,44.57$. HRMS $\mathrm{m} / \mathrm{z}$ calculated for $\mathrm{C}_{21} \mathrm{H}_{16} \mathrm{ClN}_{3} \mathrm{O}_{2}[\mathrm{M}+\mathrm{H}]+378.093$, found: 378.107 .

N'-[2-(9H-carbazol-9-yl)acetyl]-4-chlorobenzohydrazide (6): White solid, Yield 87.3\%; m.p 302-307.7 ${ }^{\circ} \mathrm{C}$. FT-IR $\left(\mathrm{ATR}, \mathrm{cm}^{-1}\right)$ : $3168(\mathrm{NH})$, 1679, $1597(\mathrm{C}=\mathrm{O}), 719(\mathrm{C}-\mathrm{Cl}) .{ }^{1} \mathrm{H}$ NMR (400 MHz, DMSO- $\left.d_{6}\right) \delta$ 
Synthesis of carbazole-based acetyl benzohydrazides targeting urease enzyme inhibition

$10.65-10.57(\mathrm{~m}, 2 \mathrm{H}), 8.17(\mathrm{~d}, J=7.7 \mathrm{~Hz}, 2 \mathrm{H}), 7.93-7.87(\mathrm{~m}, 2 \mathrm{H}), 7.64(\mathrm{~d}, J=8.2 \mathrm{~Hz}, 2 \mathrm{H}), 7.62-$ $7.55(\mathrm{~m}, 2 \mathrm{H}), 7.51-7.43(\mathrm{~m}, 3 \mathrm{H}), 7.24(\mathrm{t}, J=7.4 \mathrm{~Hz}, 2 \mathrm{H}), 5.21(\mathrm{~s}, 2 \mathrm{H}) .{ }^{13} \mathrm{C}$ NMR $(101 \mathrm{MHz}, \mathrm{DMSO})$ $\delta$ 167.46, 164.94, 141.06, 137.21, 131.49, 129.85, 129.11, 126.16, 122.78, 120.64, 119.59, 109.97, 44.57. HRMS $m / z$ calculated for $\mathrm{C}_{21} \mathrm{H}_{16} \mathrm{ClN}_{3} \mathrm{O}_{2}[\mathrm{M}+\mathrm{H}]^{+} 378.093$, found: 378.107 .

N'-[2-(9H-carbazol-9-yl)acetyl]-4-fluorobenzohydrazide (7): White solid, Yield 78.4\%; m.p 288-290 ${ }^{\circ} \mathrm{C}$. FT-IR (ATR, $\left.\mathrm{cm}^{-1}\right): 3253(\mathrm{NH}), 1685,1651(\mathrm{C}=\mathrm{O}), 1155(\mathrm{C}-\mathrm{F}) .{ }^{1} \mathrm{H}$ NMR (400 MHz, DMSO- $\left.d_{6}\right) \delta$ $10.56(\mathrm{~s}, 2 \mathrm{H}), 8.17(\mathrm{~d}, J=7.7 \mathrm{~Hz}, 2 \mathrm{H}), 7.95(\mathrm{dd}, J=8.8,5.5 \mathrm{~Hz}, 2 \mathrm{H}), 7.64(\mathrm{~d}, J=8.2 \mathrm{~Hz}, 2 \mathrm{H}), 7.46(\mathrm{q}$, $J=7.4 \mathrm{~Hz}, 2 \mathrm{H}), 7.34(\mathrm{t}, J=8.7 \mathrm{~Hz}, 2 \mathrm{H}), 7.24(\mathrm{t}, J=7.4 \mathrm{~Hz}, 2 \mathrm{H}), 5.21(\mathrm{~s}, 2 \mathrm{H}) .{ }^{13} \mathrm{C}$ NMR $(101 \mathrm{MHz}$, DMSO) $\delta 167.49,165.92,164.90,163.44,141.05,130.69,130.60,129.23,129.20,126.16,122.77$, 120.63, 119.58, 116.09, 115.87, 109.98, 44.57. HRMS $\mathrm{m} / z$ calculated for $\mathrm{C}_{21} \mathrm{H}_{16} \mathrm{FN}_{3} \mathrm{O}_{2}[\mathrm{M}+\mathrm{H}]{ }^{+}$ 362.123 , found: 362.141 .

$N^{\prime}$-[2-(9H-carbazol-9-yl)acetyl]-4-(trifluoromethyl)benzohydrazide (8): White solid, Yield 72.4\%; m.p 302-304 ${ }^{\circ} \mathrm{C}$. FT-IR (ATR, $\left.\mathrm{cm}^{-1}\right): 3186(\mathrm{NH}), 1679,1602(\mathrm{C}=\mathrm{O}), 1322\left(\mathrm{CF}_{3}\right) .{ }^{1} \mathrm{H}$ NMR $(400 \mathrm{MHz}$, DMSO- $\left.d_{6}\right) \delta 10.74(\mathrm{~d}, J=46.0 \mathrm{~Hz}, 2 \mathrm{H}), 8.17(\mathrm{~d}, J=7.7 \mathrm{~Hz}, 2 \mathrm{H}), 8.07(\mathrm{~d}, J=8.2 \mathrm{~Hz}, 2 \mathrm{H}), 7.90(\mathrm{~d}, J=$ $8.4 \mathrm{~Hz}, 2 \mathrm{H}), 7.65(\mathrm{~d}, J=8.2 \mathrm{~Hz}, 2 \mathrm{H}), 7.51-7.44(\mathrm{~m}, 2 \mathrm{H}), 7.24(\mathrm{t}, J=7.4 \mathrm{~Hz}, 2 \mathrm{H}), 5.23(\mathrm{~s}, 2 \mathrm{H}) .{ }^{13} \mathrm{C}$ NMR (101 MHz, DMSO) $\delta 167.43,164.82,141.06,136.55,132.64,132.32,132.01,131.69,128.87$, $126.17,126.05,126.02,125.66,122.95,122.79,120.64,119.60,119.44,109.97,44.58$. HRMS m/z calculated for $\mathrm{C}_{21} \mathrm{H}_{16} \mathrm{~F}_{3} \mathrm{~N}_{3} \mathrm{O}_{2}[\mathrm{M}+\mathrm{H}]+412.119$, found: 412.129 .

N'-[2-(9H-carbazol-9-yl)acetyl]-4-methoxybenzohydrazide (9): White solid, Yield 83.4\%; m.p 281-283 ${ }^{\circ} \mathrm{C}$. FT-IR (ATR, $\left.\mathrm{cm}^{-1}\right): 3182(\mathrm{NH}), 1679,1598(\mathrm{C}=\mathrm{O}), 1258\left(\mathrm{OCH}_{3}\right) .{ }^{1} \mathrm{H}$ NMR $\left(400 \mathrm{MHz}, \mathrm{DMSO}-d_{6}\right)$ $\delta 10.44(\mathrm{~s}, 2 \mathrm{H}), 8.17(\mathrm{~d}, J=7.8 \mathrm{~Hz}, 2 \mathrm{H}), 7.88(\mathrm{~d}, J=8.5 \mathrm{~Hz}, 2 \mathrm{H}), 7.65(\mathrm{~d}, J=8.2 \mathrm{~Hz}, 2 \mathrm{H}), 7.48(\mathrm{t}, J=$ $7.7 \mathrm{~Hz}, 2 \mathrm{H}), 7.24(\mathrm{t}, J=7.4 \mathrm{~Hz}, 2 \mathrm{H}), 7.03(\mathrm{~d}, J=8.5 \mathrm{~Hz}, 2 \mathrm{H}), 5.20(\mathrm{~s}, 2 \mathrm{H}), 3.82(\mathrm{~s}, 3 \mathrm{H}) .{ }^{13} \mathrm{C}$ NMR $(101$ MHz, DMSO) $\delta 167.51,165.45,162.51,141.07,129.84,126.15,126.11,124.88,122.77,120.62$, 119.57, 114.17, 110.00, 55.86, 44.59. HRMS $m / z$ calculated for $\mathrm{C}_{22} \mathrm{H}_{19} \mathrm{~F}_{3} \mathrm{~N}_{3} \mathrm{O}_{3}[\mathrm{M}+\mathrm{H}]{ }^{+} 374.144$, found: 374.159.

\subsection{Biological Assay}

\subsubsection{Urease Inhibition Assay}

The mixtures of urease $(20 \mathrm{U} / \mathrm{mL})$, urea $(100 \mathrm{mM})$, and various concentrations of test compounds $(500$ to $3.9 \mu \mathrm{M})$ were incubated in phosphate buffer for 15 minutes at $37{ }^{\circ} \mathrm{C}$. The phenol reagent $(1 \% \mathrm{w} / \mathrm{v}$ phenol and $0.005 \% \mathrm{w} / \mathrm{v}$ sodium nitroprusside) and the alkaline reagent $(0.5 \% \mathrm{w} / \mathrm{v}$ $\mathrm{NaOH}$ and $0.1 \%$ w/v NaOCl) were then added to each well. The urease activity was measured by ammonia production with the indophenol method as described by Weatherburn. After 45 minutes of incubation, the increased absorbance at $630 \mathrm{~nm}$ was measured in the microplate reader. All reactions were performed in the final volume of $360 \mu \mathrm{L}$. Thiourea and Acetohydroxamic acid, known by the trade name Lithostat ${ }^{\circledR}$ were used as the standard urease inhibitor. Finally, the results were processed with the MS Excel program.

Percent inhibition was calculated from the formula:

$\%$ Inhibition $=100-($ OD test $/$ OD control $) \times 100$.

\section{Results and Discussion}

\subsection{Chemistry}

The target compounds (compounds 3-9) were synthesized using carbazole, hydrazide, and various aromatic acid chlorides with high yields. For this purpose, seven different benzoyl chloride derivatives were used. The carbazole-based benzohydrazide derivatives were prepared through the nucleophilic addition-elimination reactions of corresponding benzoyl chloride and 2-(9H-carbazol-9-yl) 
Çapan, Org. Commun. (2021) 14:3 270-279

acetohydrazide in THF at room temperature. The structures of all newly synthesized compounds were characterized by using different spectroscopic techniques, such as FT-IR, ${ }^{1} \mathrm{H}$ NMR, ${ }^{13} \mathrm{C}$ NMR, and HRMS. The physical data, yield, melting point, molecular formula and HRMS values of all compounds are reported Table 1.

Table 1. Physical constant of carbazole-based acetyl benzohydrazides (3-9)

\begin{tabular}{ccccccc}
\hline Compound & $\begin{array}{c}\text { Yield } \\
(\boldsymbol{\%})\end{array}$ & $\mathbf{M p}\left({ }^{\circ} \mathbf{C}\right)$ & $\begin{array}{c}\text { Molecular } \\
\text { Formula }\end{array}$ & $\begin{array}{c}\text { Formula } \\
\text { Weight }\end{array}$ & \multicolumn{2}{c}{ HRMS $\boldsymbol{m} / z[\mathbf{M + H}]^{+}$} \\
Calculated & Found \\
\hline $\mathbf{3}$ & 78.5 & $265-267$ & $\mathrm{C}_{21} \mathrm{H}_{17} \mathrm{~N}_{3} \mathrm{O}_{2}$ & 343.386 & 344.13 & 344.156 \\
$\mathbf{4}$ & 83.6 & $235-237$ & $\mathrm{C}_{21} \mathrm{H}_{16} \mathrm{ClN}_{3} \mathrm{O}_{2}$ & 377.828 & 378.093 & 378.107 \\
$\mathbf{5}$ & 80.2 & $268-270$ & $\mathrm{C}_{21} \mathrm{H}_{16} \mathrm{ClN}_{3} \mathrm{O}_{2}$ & 377.828 & 378.093 & 378.107 \\
$\mathbf{6}$ & 87.3 & $302-307.7$ & $\mathrm{C}_{21} \mathrm{H}_{16} \mathrm{ClN}_{3} \mathrm{O}_{2}$ & 377.828 & 378.093 & 378.107 \\
$\mathbf{7}$ & 78.4 & $288-290$ & $\mathrm{C}_{21} \mathrm{H}_{16} \mathrm{FN}_{3} \mathrm{O}_{2}$ & 361.376 & 362.123 & 362.141 \\
$\mathbf{8}$ & 72.4 & $302-304$ & $\mathrm{C}_{21} \mathrm{H}_{16} \mathrm{~F}_{3} \mathrm{~N}_{3} \mathrm{O}_{2}$ & 411.384 & 412.119 & 412.129 \\
$\mathbf{9}$ & 83.4 & $281-283$ & $\mathrm{C}_{22} \mathrm{H}_{19} \mathrm{~F}_{3} \mathrm{~N}_{3} \mathrm{O}_{3}$ & 373.412 & 374.144 & 374.159 \\
\hline
\end{tabular}
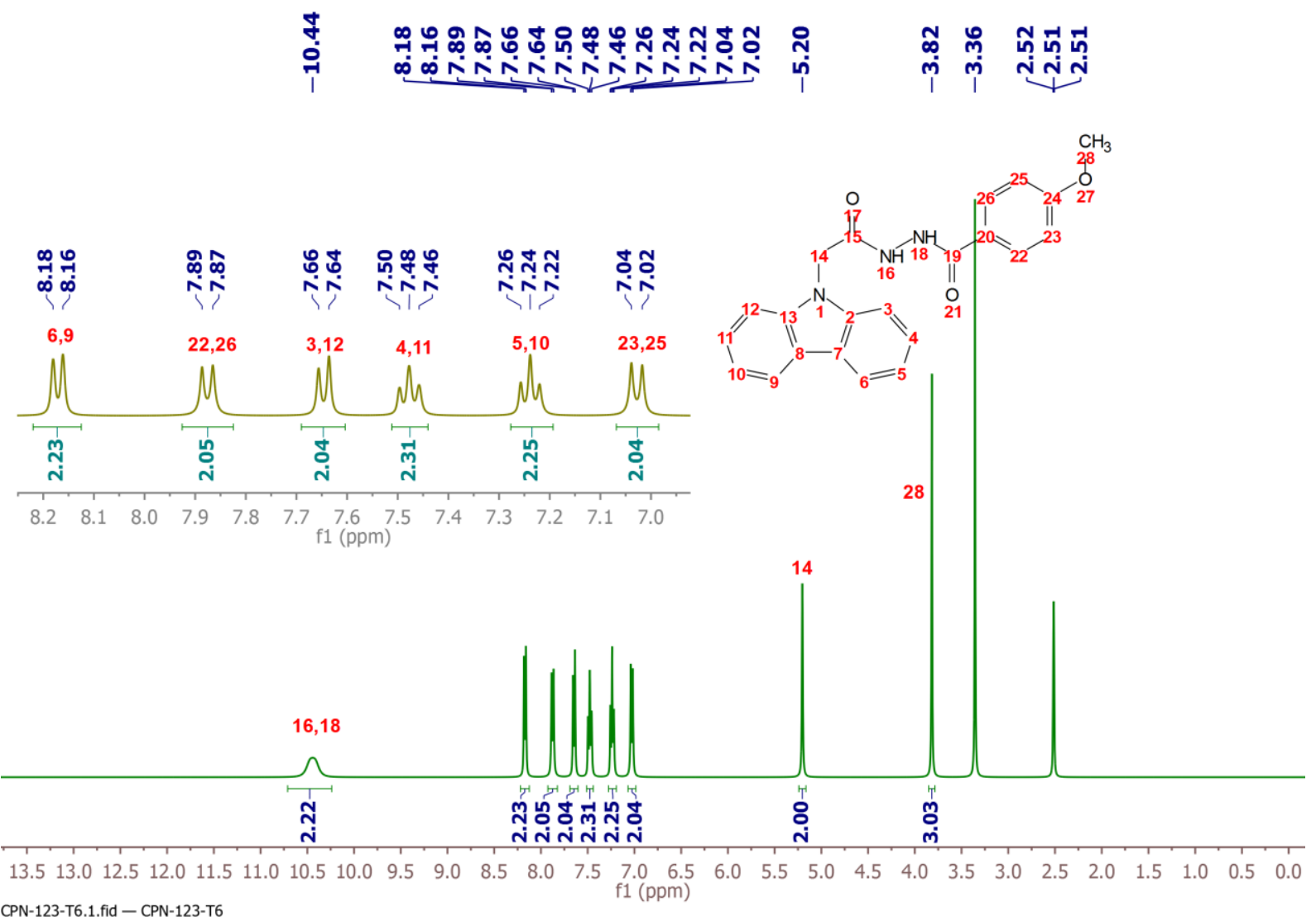

CPN-123-T6.1. fid - CPN-123-T6

Figure 3. ${ }^{1} \mathrm{H}$ NMR spectra of compound 9

As an example, one of the synthesized target compounds, compound 9, was chosen and The FTIR, ${ }^{1} \mathrm{H}$ NMR, ${ }^{13} \mathrm{C}$ NMR, and HETCOR spectra were interpreted, and spectroscopic characterization was detailed by analyzing the signals of functional groups and atoms. FT-IR spectra of all compounds were taken by the ATR method. In the FT-IR spectrum of this compound, the sharp band of NH stretching vibrations starting from $3182 \mathrm{~cm}^{-1}$ and aromatic and aliphatic C-H stretching vibrations were observed in the range of $3048-2959 \mathrm{~cm}^{-1}$. Moreover, two different stretching vibrations belonging to $\mathrm{C}=\mathrm{O}$ groups were observed at 1679 and $1598 \mathrm{~cm}^{-1}$. In addition, $\mathrm{C}=\mathrm{C}$ stretching vibrations were observed in the range of $1595-1420 \mathrm{~cm}^{-1}$, while the specific signal belonging to the $\mathrm{O}-\mathrm{CH}_{3}$ functional group was observed at $1258 \mathrm{~cm}^{-1}$. 
Synthesis of carbazole-based acetyl benzohydrazides targeting urease enzyme inhibition

The ${ }^{1} \mathrm{H}$ NMR spectrum of compound 9 given in Figure 3 showed: The signal belonging to $\mathrm{NH}$ protons was seen as broad at $\delta 10.44 \mathrm{ppm}$. The signal, seen as a doublet at $\delta 8.17 \mathrm{ppm}$, belongs to protons bonded to C-6 and C-9 carbons of the carbazole ring, and the coupling constant $(J)$ is $7.8 \mathrm{~Hz}$. the signals of the H-22, H-26, H-23, and $\mathrm{H}-25$ protons belonging to the anisole part of the compound, were observed at $\delta 7.88$ and $\delta 7.03 \mathrm{ppm}$ as a doublet, respectively, and the coupling constants of these signals are $8.5 \mathrm{~Hz}$. The doublet signals of the $\mathrm{H}-3$ and $\mathrm{H}-12$ protons belonging to the carbazole ring were observed at $\delta 7.65 \mathrm{ppm}$ and the coupling constant is $8.2 \mathrm{~Hz}$. In addition, the signals of the $\mathrm{H}-4, \mathrm{H}-11$, $\mathrm{H}-5$, and $\mathrm{H}-10$ protons appeared at $\delta 7.7$ and $\delta 7.4$ as triplets, respectively. The singlet signal of the $\mathrm{H}-$ 14 proton equivalent to two protons was observed at $\delta 5.30 \mathrm{ppm}$. Finally, the methoxy group of the anisole appeared as a singlet at $\delta 3.82 \mathrm{ppm}$.

In the ${ }^{13} \mathrm{C}$ NMR spectrum given in Figure 4 of compound 9 dissolved in DMSO- $\mathrm{d}_{6}$, the signals of carbonyl carbons (C-15 and C-19) belonging to the acyl benzohydrazide system were observed at 167.51, $165.45 \mathrm{ppm}$, respectively. The signals of ipso carbons (C-24 and C-20) belonging to the methoxyphenyl ring arosed at 162.51 and $124.88 \mathrm{ppm}$, while the signals of ipso carbons of the carbazole ring (C-3, C-12, C-7, and C-8) were seen at 141.07 and $122.77 \mathrm{ppm}$, respectively. Whereas the signals of aromatic- $\mathrm{CH}$ carbons $(\mathrm{C}-22, \mathrm{C}-26, \mathrm{C}-23$, and C-25) of the anisole part appeared at 129.84 and 114.17 $\mathrm{ppm}$, the signals of the aromatic - $\mathrm{CH}$ carbons of the carbazole ring $(\mathrm{C}-4, \mathrm{C}-11, \mathrm{C}-6$, and $\mathrm{C}-9)$ were seen at 126.15 and $120.62 \mathrm{ppm}$. The signals of the others (C-5, C-10, C-3, and C-12) carbons were observed at 119.57 and $110 \mathrm{ppm}$, respectively. Furthermore, methoxy carbon (C-28) was viewed at $55.86 \mathrm{ppm}$, while methylene carbon (C-14) was observed at $44.59 \mathrm{ppm}$.

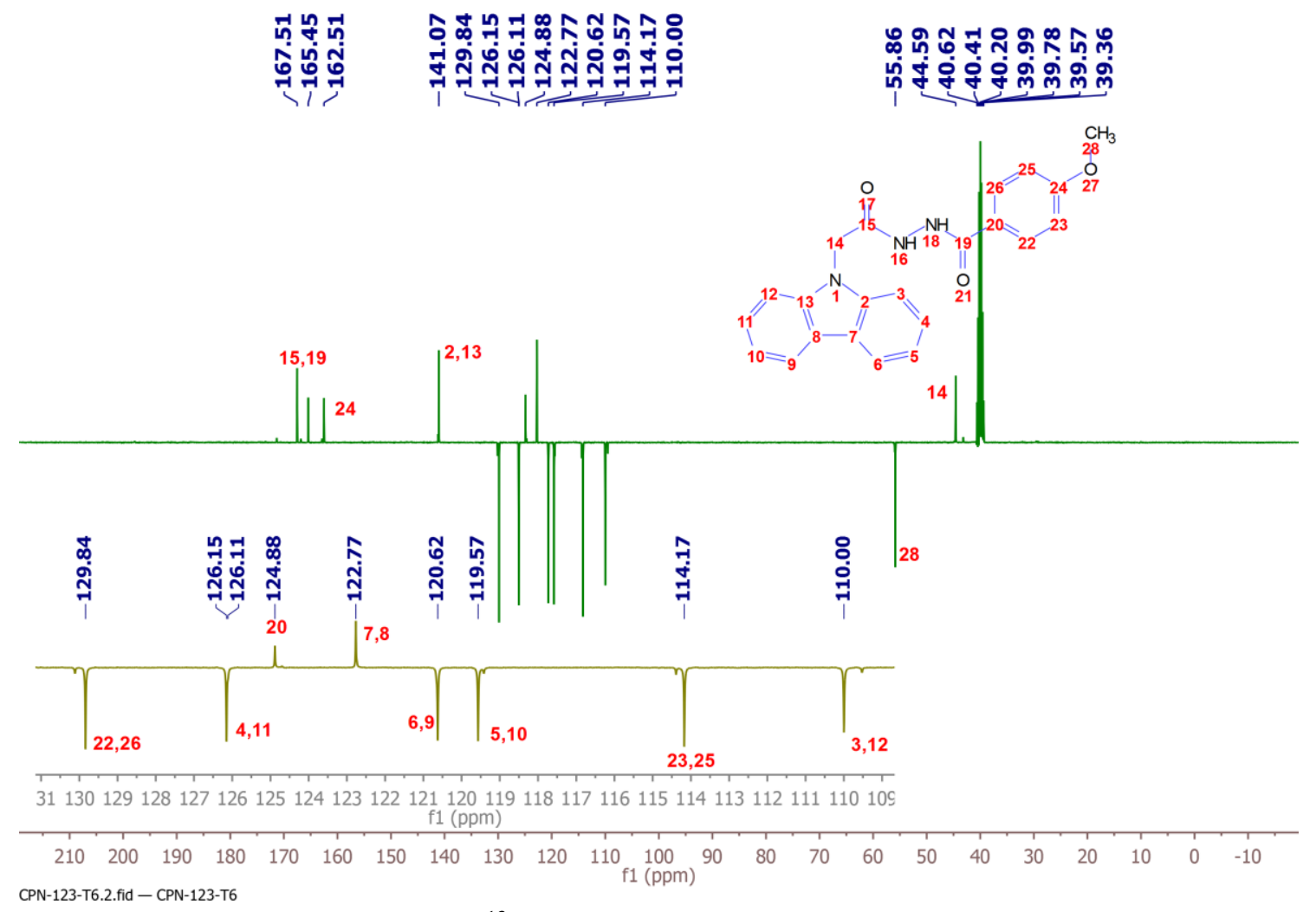

Figure 4. ${ }^{13} \mathrm{C}$ NMR spectra of compound 9

In the HETCOR spectrum of compound 9 , the chemical shifts of the directly bound protons and carbons and the signals seen in the contour plot are compatible with the ${ }^{1} \mathrm{H}$ and ${ }^{13} \mathrm{C}$ NMR spectra (Figure 5). Since there are no directly bound protons to the quaternary carbons, the signals at 167.51-141.01, 124.88 , and $122.77 \mathrm{ppm}$ belong to the quaternary carbons and did not result in any correlation $\left({ }^{1} J_{\mathrm{CH}}\right)$. The peaks at 129.84, 126.15, and 120.62-110.00 ppm are the aromatic carbon signals, which are bonded with the aromatic proton signals present at $8.17-7.03 \mathrm{ppm}$. The peak (a) at $55.86 \mathrm{ppm}$ is directly bonded to the singlet $\left(-\mathrm{OCH}_{3}\right)$ at $3.82 \mathrm{ppm}$, while the peak (b) at $44.59 \mathrm{ppm}$ is directly bonded to the singlet (- 
Çapan, Org. Commun. (2021) 14:3 270-279

$\mathrm{CH}_{2}$ ) at $5.20 \mathrm{ppm}$. The ${ }^{1} \mathrm{H}$ NMR and ${ }^{13} \mathrm{C}_{\mathrm{APT}} \mathrm{NMR}$ data of the compound 9 molecule described all the carbon and hydrogen atoms in the molecule. Similarly, the spectroscopic analysis data for the other synthesized compounds confirmed the structures of the relating compounds. (See Supporting information file of the article).

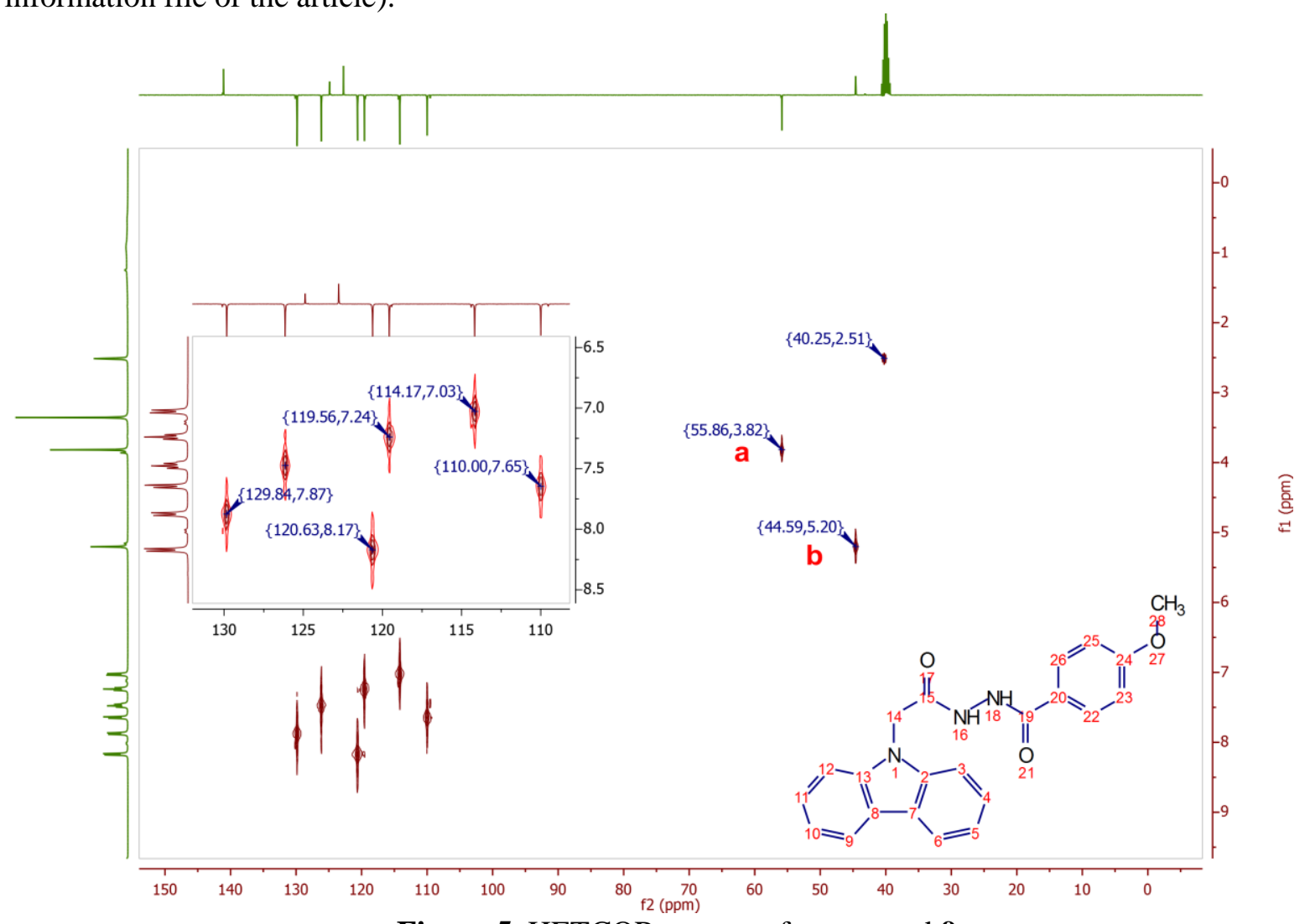

Figure 5. HETCOR spectra of compound 9

\subsection{Biological Assay}

\subsubsection{Urease Inhibition Assay}

The in-vitro anti-urease activity of the synthesized compounds was investigated using Jack bean urease as the model enzyme. The $\mathrm{IC}_{50}$ values of acetohydroxamic acid and thiourea, which are standard urease inhibitors, were calculated as $15,96 \pm 0,037$ and $21,41 \pm 0,023 \mu \mathrm{M}$, respectively. The $\mathrm{IC}_{50}$ value of compound 3, which is the most effective molecule, was found to be $4.90 \pm 0,041 \mu \mathrm{M}$ (Table 2).

Table 2. Urease inhibitory activity of carbazole-based acetyl benzohydrazides (3-9)

\begin{tabular}{cc}
\hline Compound & $\mathbf{I C}_{\mathbf{5 0}}(\boldsymbol{\mu M})^{*}$ \\
\hline $\mathbf{3}$ & $\mathbf{4 . 9 0} \pm \mathbf{0 . 0 4 1}$ \\
$\mathbf{4}$ & $11.06 \pm 0.036$ \\
$\mathbf{5}$ & $10.40 \pm 0.057$ \\
$\mathbf{6}$ & $9.24 \pm 0.073$ \\
$\mathbf{7}$ & $9,65 \pm 0.046$ \\
$\mathbf{8}$ & $11.15 \pm 0.053$ \\
$\mathbf{9}$ & $7.68 \pm 0.041$ \\
Acetohydroxamic acid $^{\text {(std) }}$ & $15.96 \pm 0.037$ \\
Thiourea $^{\text {(std) }}$ & $21.41 \pm 0.023$ \\
\hline
\end{tabular}

$* \overline{\text { Values were thmeans of three replicates } \pm \text { standard deviation }}$ 
Synthesis of carbazole-based acetyl benzohydrazides targeting urease enzyme inhibition

To better understand the structure-activity relationship, when the compounds containing chlorine atoms in different positions of the phenyl ring were examined, it was found that compound $\mathbf{6}$ with chlorine in the $p$-position was more active than those in the $o$ - and $m$-positions. Compound 7 with fluorine atom instead of chlorine in the $p$-position showed less activity than compound $\mathbf{6}$. Similarly, compound 9 with $-\mathrm{OCH}_{3}$ group at the $p$-position was found to be more active than compound $\mathbf{8}$ with $-\mathrm{CF}_{3}$ group at the same position.

\section{Conclusion}

The seven novel carbazole-based acetyl benzohydrazide derivatives were synthesized and characterized by using FT-IR, ${ }^{1} \mathrm{H}$ NMR, ${ }^{13} \mathrm{C}$ NMR, and HRMS techniques. The urease enzyme activities of these compounds were investigated using Jack bean urease as the model enzyme. Among the compounds containing chlorine atoms in different positions of the phenyl ring, the $p$-position was found to be more active than the $o$ - and $m$-positions. A decrease in activity was observed when the chlorine atom at the $p$-position was replaced by the fluorine atom. It was found that $-\mathrm{OCH}_{3}$ at the $p$-position was more active than $-\mathrm{CF}_{3}$ at the same position. Compound $\mathbf{3}$ was found to be the most effective molecule in urease enzyme inhibition. The substitutions with phenyl-linked functional groups around the carbazole skeleton showed a decisive effect on urease inhibitory activity.

\section{Supporting Information}

Supporting information accompanies this paper on http://www.acgpubs.org/journal/organic$\underline{\text { communications }}$

\section{ORCID}

İrfan Çapan: $\underline{0000-0002-9555-1555}$

\section{References}

[1] Gluszynska, A. Biological potential of carbazole derivatives. Eur J Med Chem 2015, 94, 405-26.

[2] Zhang, F. F.; Gan, L. L.; Zhou, C. H. Synthesis, antibacterial and antifungal activities of some carbazole derivatives. Bioorg. Med. Chem. Lett. 2010, 20 (6), 1881-4.

[3] Salih, N.; Salimon, J.; Yousif, E. Synthesis and antimicrobial activities of 9H-carbazole derivatives. Arab. J. Chem. 2016, 9, S781-S786.

[4] Ibrar, A.; Kazmi, M.; Khan, A.; Halim, S. A.; Saeed, A.; Mehsud, S.; Al-Harrasi, A.; Khan, I. Robust therapeutic potential of carbazole-triazine hybrids as a new class of urease inhibitors: A distinctive combination of nitrogen-containing heterocycles. Bioorg. Chem. 2020, 95, 103479.

[5] Ashok, D.; Ravi, S.; Ganesh, A.; Lakshmi, B. V.; Adam, S.; Murthy, S. D. S. Microwave-assisted synthesis and biological evaluation of carbazole-based chalcones, aurones and flavones. Med. Chem. Res. 2016, 25 (5), 909-922.

[6] Rad, M. N. S.; Behrouz, S.; Behrouz, M.; Sami, A.; Mardkhoshnood, M.; Zarenezhad, A.; Zarenezhad, E. Design, synthesis and biological evaluation of novel 1,2,3-triazolyl $\beta$-hydroxy alkyl/carbazole hybrid molecules. Molecular Divers. 2016, 20 (3), 705-718.

[7] Knölker, H.-J.; Reddy, K. R. Isolation and synthesis of biologically active carbazole alkaloids. Chem. Rev. 2002, 102 (11), 4303-4428.

[8] Ito, C.; Itoigawa, M.; Aizawa, K.; Yoshida, K.; Ruangrungsi, N.; Furukawa, H. Gamma-lactone carbazoles from Clausena anisata. J. Nat. Prod. 2009, 72 (6), 1202-1204.

[9] Caruso, A.; Ceramella, J.; Iacopetta, D.; Saturnino, C.; Mauro, M. V.; Bruno, R.; Aquaro, S.; Sinicropi, M. S. Carbazole derivatives as antiviral agents: an overview. Molecules 2019, 24 (10), 1912.

[10] Archer, S.; Ross, B. S.; Pica-Mattoccia, L.; Cioli, D. Synthesis and biological properties of some 6Hpyrido[4,3-b]carbazoles. J. Med. Chem. 1987, 30 (7), 1204-1210. 
Çapan, Org. Commun. (2021) 14:3 270-279

[11] Arun, A.; Patel, O. P. S.; Saini, D.; Yadav, P. P.; Konwar, R. Anti-colon cancer activity of Murraya koenigii leaves is due to constituent murrayazoline and O-methylmurrayamine A induced mTOR/AKT downregulation and mitochondrial apoptosis. Biomed. Pharmacothe.r 2017, 93, 510-521.

[12] Hirata, K.; Ito, C.; Furukawa, H.; Itoigawa, M.; Cosentino, L. M.; Lee, K. H. Substituted 7H-pyrido[4,3c]carbazoles with potent anti-HIV activity. Bioorg. Med. Chem. Lett. 1999, 9 (2), 119-122.

[13] Furukawa, Y.; Sawamoto, A.; Yamaoka, M.; Nakaya, M.; Hieda, Y.; Choshi, T.; Hatae, N.; Okuyama, S.; Nakajima, M.; Hibino, S. Effects of carbazole derivatives on neurite outgrowth and hydrogen peroxideinduced cytotoxicity in neuro2a cells. Molecules 2019, 24 (7), 1366.

[14] Abbas, A.; Ali, B.; Kanwal; Khan, K. M.; Iqbal, J.; ur Rahman, S.; Zaib, S.; Perveen, S. Synthesis and in vitro urease inhibitory activity of benzohydrazide derivatives, in silico and kinetic studies. Bioorg. Chem. 2019, 82, 163-177.

[15] Önkol, T.; Gökçe, M.; Orhan, İ.; Kaynak, F. Design, synthesis and evaluation of some novel 3(2H)pyridazinone-2-yl acetohydrazides as acetylcholinesterase and butyrylcholnesterase inhibitors. Org. Commun. 2013, 6 (1), 55-67.

[16] Doğan, İ. S.; Sellitepe, H. E.; Kayıkçı, N.; Sipahi, H.; Reis, R.; Yaylı, N. Synthesis and anticancer (MCF7, PC-3) activities of new 2-hydroxy-2,2-bis(4-substitutedphenyl)- $N$-[(1E)-(3/4-substitutedphenyl)methylene]-acetohydrazides. Org. Commun. 2018, 11 (3), 142-148.

[17] Rollas, S.; Küçükgüzel, S. G. Biological activities of hydrazone derivatives. Molecules 2007, 12 (8), 19101939.

[18] Arjunan, V.; Jayaprakash, A.; Carthigayan, K.; Periandy, S.; Mohan, S. Conformational, structural, vibrational and quantum chemical analysis on 4-aminobenzohydrazide and 4-hydroxybenzohydrazide-a comparative study. Spectrochim Acta A Mol. Biomol. Spectrosc. 2013, 108, 100-114.

[19] Rego, Y. F.; Queiroz, M. P.; Brito, T. O.; Carvalho, P. G.; de Queiroz, V. T.; de Fátima, Â.; Macedo Jr, F. A review on the development of urease inhibitors as antimicrobial agents against pathogenic bacteria. $J$. Adv. Res. 2018, 13, 69-100.

[20] Khan, A. W.; Jan, S.; Parveen, S.; Khan, R. A.; Saeed, A.; Tanveer, A. J.; Shad, A. A. Phytochemical analysis and enzyme inhibition assay of Aerva javanica for Ulcer. Chem. Centr. J. 2012, 6 (1), 76.

[21] Hanif, M.; Shoaib, K.; Saleem, M.; Hasan Rama, N.; Zaib, S.; Iqbal, J. Synthesis, ureaseinhibition, antioxidant, antibacterial, and molecular docking studies of 1,3,4-oxadiazole derivatives. ISRN Pharmacol. 2012, 2012, 928901.

[22] Hameed, A.; Al-Rashida, M.; Uroos, M.; Qazi, S. U.; Naz, S.; Ishtiaq, M.; Khan, K. M. A patent update on therapeutic applications of urease inhibitors (2012-2018). Expert Opin. Therapeut.Patents 2019, 29 (3), 181-189.

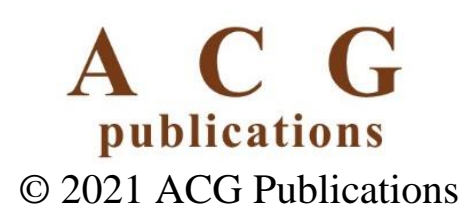

